\title{
Cytopathology in the post mortem room
}

\author{
E Walker, J J Going
}

\begin{abstract}
Aim-To demonstrate the role of cytopathology in examining tumours found at post mortem examination. Methods-Tumour deposits were found in 25 hospital necropsies. Cytological diagnosis made at the time of necropsy was compared with subsequent paraffin wax embedded histological sections.

Results-In 19 out of 20 cases with no previous histological diagnosis, cytology at the time of necropsy provided rapid and accurate assessment of tumour type. Subsequent histological examination of formalin fixed material merely refined the diagnosis in some cases. In the remaining five cases in which tumour type was known, cytological examination of deposits found at necropsy provided extra information that was useful for compiling a provisional report.

Conclusions-Rapid cytological examination of tumours found during post mortem examinations provides accurate relevant information which can be used to produce a more comprehensive provisional necropsy report. The technique has advantages over frozen section histology and can provide useful cytological experience for histopathology trainees.
\end{abstract}

(F Clin Pathol 1994;47:714-717)

Hospital necropsies are often performed on patients with malignant tumours. Despite the sophistication of modern methods of investigation, many necropsies reveal undiagnosed or even unsuspected tumours. Of 223 routine hospital necropsies carried out during 1992 at Glasgow Royal Infirmary, $64(28 \cdot 7 \%)$ showed malignant tumours, $40(62.5 \%)$ with no prior histological or cytological diagnosis and 25 (39\%) unsuspected clinically. Pathologists should, whenever possible, provide a microscopic assessment of such previously undiagnosed tumours at the time of necropsy. Usually frozen section histology is suitable for typing such tumours. However, this has disadvantages when applied to necropsy material. The technique requires an MLSO's time and therefore usually only a single sample from one site is examined. Necropsy frozen sections are often of poor quality and there is a risk of cryostat contamination with infective agents.

\section{Methods}

A series of 25 recent routine hospital necropsy cases illustrates the use of cytology in the post mortem room in a variety of situations. Relevant clinical data and necropsy findings are given in the table. Although most of these cases were included because they deal with previously undiagnosed tumours, some cases illustrate the use of cytology in which there was recognised tumour with specific diagnosis, but some question arising at the time of necropsy required clarification. Cases were not chosen merely because cytological and histological diagnoses were in agreement.

Slides were prepared using "scrape cytology". ${ }^{1}$ A freshly cut surface of tumour was scraped gently with a clean scalpel blade. The resulting fluid with tumour cells was dotted on to one end of a glass slide and a smear of the material made with a second clean slide in the conventional manner. Such smears were treated in two ways. Air dried smears were fixed and stained using the Diff Quik method (Baxter Healthcare Ltd). Smears fixed immediately in $95 \%$ ethanol for one to two minutes were stained using haematoxylin and eosin Preparation time by the Diff Quik method was up to five minutes while haematoxylin and eosin stained slides took about $10 \mathrm{~min}$ utes. Alcohol fixed smears were also used for glycogen or mucin staining using conventional periodic acid Schiff (PAS) or PASdiastase methods, respectively.

\section{Results}

In general the quality of necropsy based cytological material was good, in some cases it was actually better than tissue retained for conventional paraffin wax histology. It was useful to have both air dried and alcohol fixed material. Although staining by the Diff Quik method was the most rapid, alcohol fixed smears were useful for special stains such as PAS-diastase for mucin.

The table summarises the clinical and necropsy details together with cytological and histological findings in the 25 cases. Twenty concern patients with no previous pathological diagnosis of tumour. These cases illustrate typical problems for which rapid confirmation of tumour type is desirable for the production of a relatively complete report on the day of necropsy.

The cases fall into distinct categories. Cases 1-5 demonstrate the assessment of lung tumours. This is useful where multiple or 
Details of cases coming to necropsy with post mortem and subsequent histological findings

\begin{tabular}{|c|c|c|c|}
\hline $\begin{array}{l}\text { Case No } \\
\text { (sex, age) }\end{array}$ & Gross findings at necropsy & $\begin{array}{l}\text { Cytological diagnosis } \\
\text { at time of necropsy }\end{array}$ & $\begin{array}{l}\text { Subsequent paraffin wax } \\
\text { embedded histology }\end{array}$ \\
\hline $1(\mathrm{M}, 80)^{\star} \dagger$ & $\begin{array}{l}\text { Widespread tumour, unilateral lung } \\
\text { deposits }\end{array}$ & Small cell carcinoma & Confirms cytology \\
\hline $2(M, 56)^{\star}$ & $\begin{array}{l}\text { Widespread tumour, bilateral lung } \\
\text { deposits }\end{array}$ & Small cell carcinoma & Confirms cytology \\
\hline $\begin{array}{l}3(\mathrm{~F}, 58)^{\star} \dagger \\
4(\mathrm{M}, 72)^{\star}\end{array}$ & $\begin{array}{l}\text { Lung tumour, widespread metastases } \\
\text { Lung tumour, widespread metastases }\end{array}$ & $\begin{array}{l}\text { Small cell carcinoma } \\
\text { Poorly differentiated } \\
\text { non-small cell carcinoma }\end{array}$ & $\begin{array}{l}\text { Confirms cytology } \\
\text { Large cell undifferentiated } \\
\text { carcinoma }\end{array}$ \\
\hline $\begin{array}{l}5(\mathrm{M}, 68)^{\star} \\
6(\mathrm{~F}, 84)^{\star} \dagger \\
7(\mathrm{~F}, 63)^{\star}\end{array}$ & $\begin{array}{l}\text { Lung tumour } \\
\text { Gastric tumour, hepatic metastases } \\
\text { Sclerotic mass in left lobe of liver, }\end{array}$ & $\begin{array}{l}\text { Adenocarcinoma } \\
\text { Adenocarcinoma } \\
\text { Probable intrahepatic }\end{array}$ & $\begin{array}{l}\text { Confirms cytology } \\
\text { Confirms cytology }\end{array}$ \\
\hline $8(M, 53)^{\star}$ & $\begin{array}{l}\text { multiple deposits in right lobe } \\
\text { Intraabdominal metastases, } \\
\text { small mass in pancreas }\end{array}$ & $\begin{array}{l}\text { cholangiocarcinoma } \\
\text { Adenocarcinoma }\end{array}$ & $\begin{array}{l}\text { Confirms cytology } \\
\text { Confirms cytology }\end{array}$ \\
\hline $\begin{array}{l}9(M, 86)^{\star} \\
10(M, 49)^{\star} \dagger \\
11(M, 74)^{\star} \\
12(M, 64)^{\star} \dagger\end{array}$ & $\begin{array}{l}\text { Multiple hepatic deposits } \\
\text { Widespread tumour } \\
\text { Widespread tumour, mass in rectum } \\
\text { Widespread tumour, small nodule in } \\
\text { pancreas }\end{array}$ & $\begin{array}{l}\text { Hepatocellular carcinoma } \\
\text { Renal carcinoma } \\
\text { Adenocarcinoma } \\
\text { Adenocarcinoma }\end{array}$ & $\begin{array}{l}\text { Confirms cytology } \\
\text { Confirms cytology } \\
\text { Confirms cytology } \\
\text { Confirms cytology }\end{array}$ \\
\hline $13(\mathrm{~F}, 85)^{\star} \dagger$ & $\begin{array}{l}\text { Thickened gallbladder with obliteration of } \\
\text { lumen }\end{array}$ & Adenocarcinoma & Confirms cytology \\
\hline $14(M, 77)^{\star} \dagger$ & Focal constriction of ascending colon & Carcinoma & $\begin{array}{l}\text { Moderately differentiated } \\
\text { adenocarcinoma }\end{array}$ \\
\hline $15(F, 67)^{\star}$ & $\begin{array}{l}\text { Clinical suspicion of bone metastases. } \\
\text { No gross tumour at autopsy } \\
\text { ? microscopic tumour in marrow }\end{array}$ & No tumour identified & $\begin{array}{l}\text { Metastatic undifferentiated } \\
\text { carcinoma ? source }\end{array}$ \\
\hline $16(F, 96)^{\star} \dagger$ & Large bowel and renal tumours & $\begin{array}{l}\text { Separate primary colonic } \\
\text { and renal carcinomas }\end{array}$ & Confirms cytology \\
\hline $17(\mathrm{~F}, 72)^{\star} \dagger$ & $\begin{array}{l}\text { Generalised lymphadenopathy, } \\
\text { hepatosplenomegaly }\end{array}$ & Non-Hodgkin's lymphoma & $\begin{array}{l}\text { Non-Hodgkin's lymphoma- } \\
\text { small B cell type }\end{array}$ \\
\hline $18(M, 61)^{\star}$ & $\begin{array}{l}\text { Hilar lymphadenopathy, splenomegaly, } \\
\text { multiple hepatic deposits }\end{array}$ & $\begin{array}{l}\text { Lymphoma, possibly } \\
\text { Hodgkin's lymphoma }\end{array}$ & $\begin{array}{l}\text { Lymphocyte predominant } \\
\text { Hodgkin's lymphoma }\end{array}$ \\
\hline $19(M, 70)^{\star} \dagger$ & $\begin{array}{l}\text { Retroperitoneal mass, myocardial } \\
\text { deposits }\end{array}$ & Non-Hodgkin's lymphoma & $\begin{array}{l}\text { Non-Hodgkin's lymphoma- } \\
\text { centroblastic type }\end{array}$ \\
\hline $\begin{array}{l}20(\mathrm{~F}, 83)^{\star} \dagger \\
21(\mathrm{M}, 54)\end{array}$ & $\begin{array}{l}\text { Mass arising from gastric greater curve } \\
\text { Known adenoid cystic carcinoma. } \\
\text { Sclerotic mass around left temporal bone }\end{array}$ & $\begin{array}{l}\text { Benign stromal tumour } \\
\text { Recurrent adenoid cystic } \\
\text { carcinoma }\end{array}$ & $\begin{array}{l}\text { Confirms cytology } \\
\text { Confirms cytology }\end{array}$ \\
\hline $22(M, 49)$ & $\begin{array}{l}\text { Known non-Hodgkin's lymphoma. } \\
\text { Lymph node and hepatic deposits }\end{array}$ & Recurrent lymphoma & $\begin{array}{l}\text { Probable anaplastic } \\
\text { transformation of previous } \\
\text { non-Hodgkin's lymphoma }\end{array}$ \\
\hline $23(M, 59)$ & $\begin{array}{l}\text { Previous squamous carcinoma of } \\
\text { oesophagus and second primary rectal } \\
\text { adenocarcinoma. Widespread tumour }\end{array}$ & Metastatic adenocarcinoma & Confirms cytology \\
\hline $24(M, 67)$ & $\begin{array}{l}\text { Previous bladder carcinoma, Caecal tumour, } \\
\text { renal tumour and widespread metastases }\end{array}$ & $\begin{array}{l}\text { (i) Primary caecal } \\
\text { adenocarcinoma } \\
\text { (ii) Primary renal carcinoma } \\
\text { (iii) Metastases from caecal } \\
\text { adenocarcinoma }\end{array}$ & Confirms cytology \\
\hline $25(M, 56)$ & $\begin{array}{l}\text { Previous small bowel carcinoid. } \\
\text { Widespread tumour }\end{array}$ & Metastatic carcinoid tumour & Confirms cytology \\
\hline
\end{tabular}

^No previous histological or cytological diagnosis; trumour unsuspected clinically.

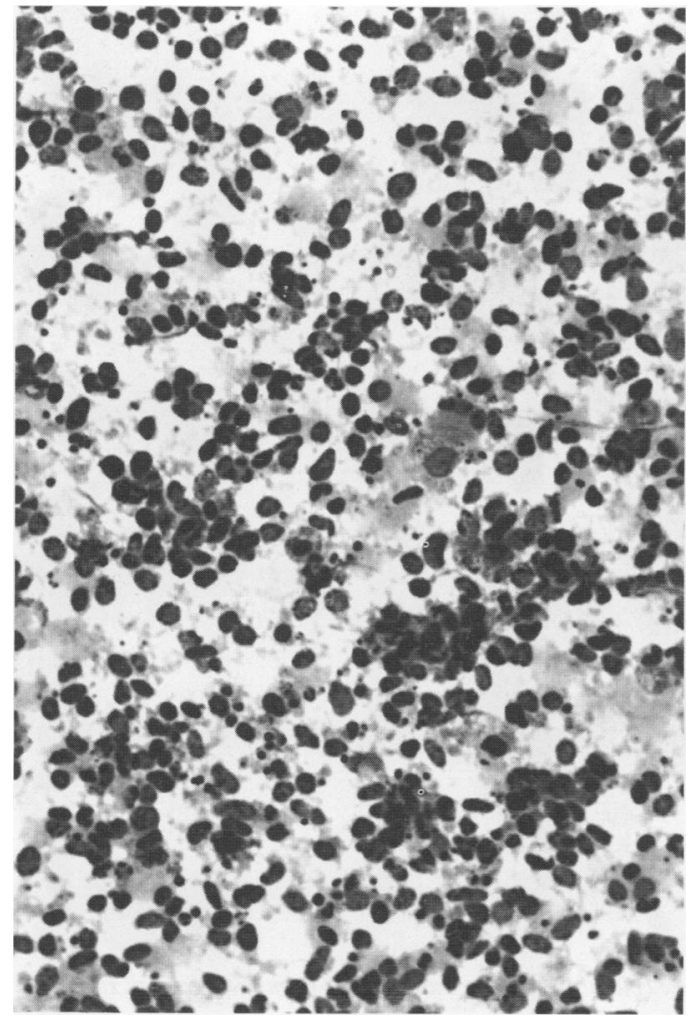

Figure 1 Case 2: primary bronchial small cell carcinoma (haematoxylin and eosin).

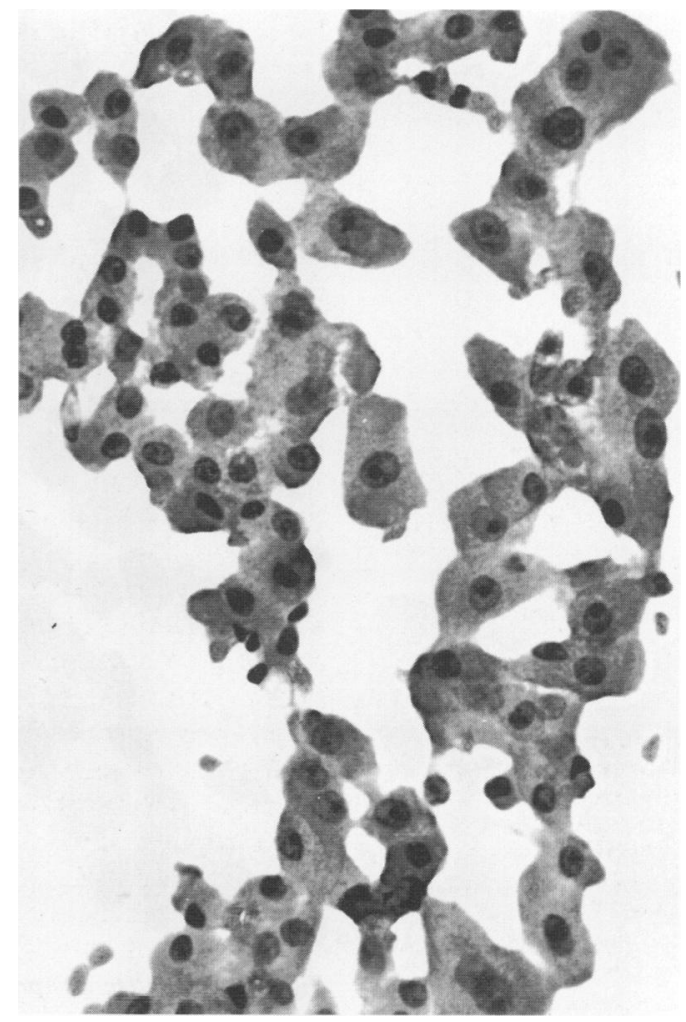

Figure 2 Case 9: primary hepatocellular carcinoma (haematoxylin and eosin). 


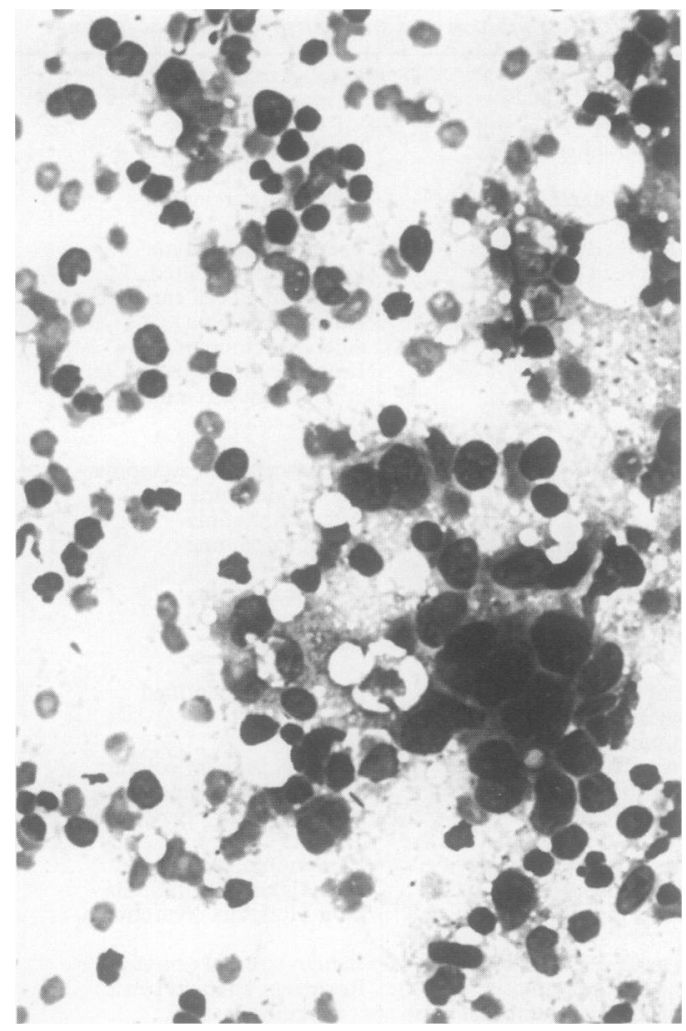

Figure 3 Case 15: metastatic undifferentiated carcinoma in bone marrow (Diff Quik).

bilateral tumour deposits are present and there is doubt as to whether these are from a primary lung tumour. Case 2 (fig 1) illustrates a primary small cell carcinoma of lung with multiple bilateral pulmonary metastases.

Cases 6-12 illustrate similar problems of multiple intraabdominal tumour deposits. Multiple hepatic tumour deposits do not necessarily indicate metastases (case 9) (fig 2). Typing of hepatic metastatic tumour deposits can also suggest likely sites of an elusive small primary-as in case 12 .

Indistinct gross tumour deposits which might otherwise be taken for inflammatory lesions can be examined rapidly by cytology (cases 13 and 14). In case 15 bone metastases were suspected clinically but no histological diagnosis had been made and no gross tumour deposits were evident at necropsy. At the time of necropsy no malignant cells were noted in cytological smears made from bone marrow. In retrospect, undifferentiated carcinoma cells were present in these smears (fig 3). Two previously undiagnosed separate primary carcinomas (case 16) (fig 4) were clearly resolved by cytological examination. Staining using PAS with and without diastase on alcohol fixed smears proved particularly useful in this case.

Several previously undiagnosed lymphomas were encountered and these were differentiated from carcinomas (cases 17-19) (fig 5). One benign tumour found during the examination was diagnosed using scrape cytology (case 20).

Rapid confirmation of the nature of tumour deposits also proved useful in many cases with previous histological diagnoses (cases 21-25) allowing the pathologist to give a more comprehensive preliminary necropsy report.
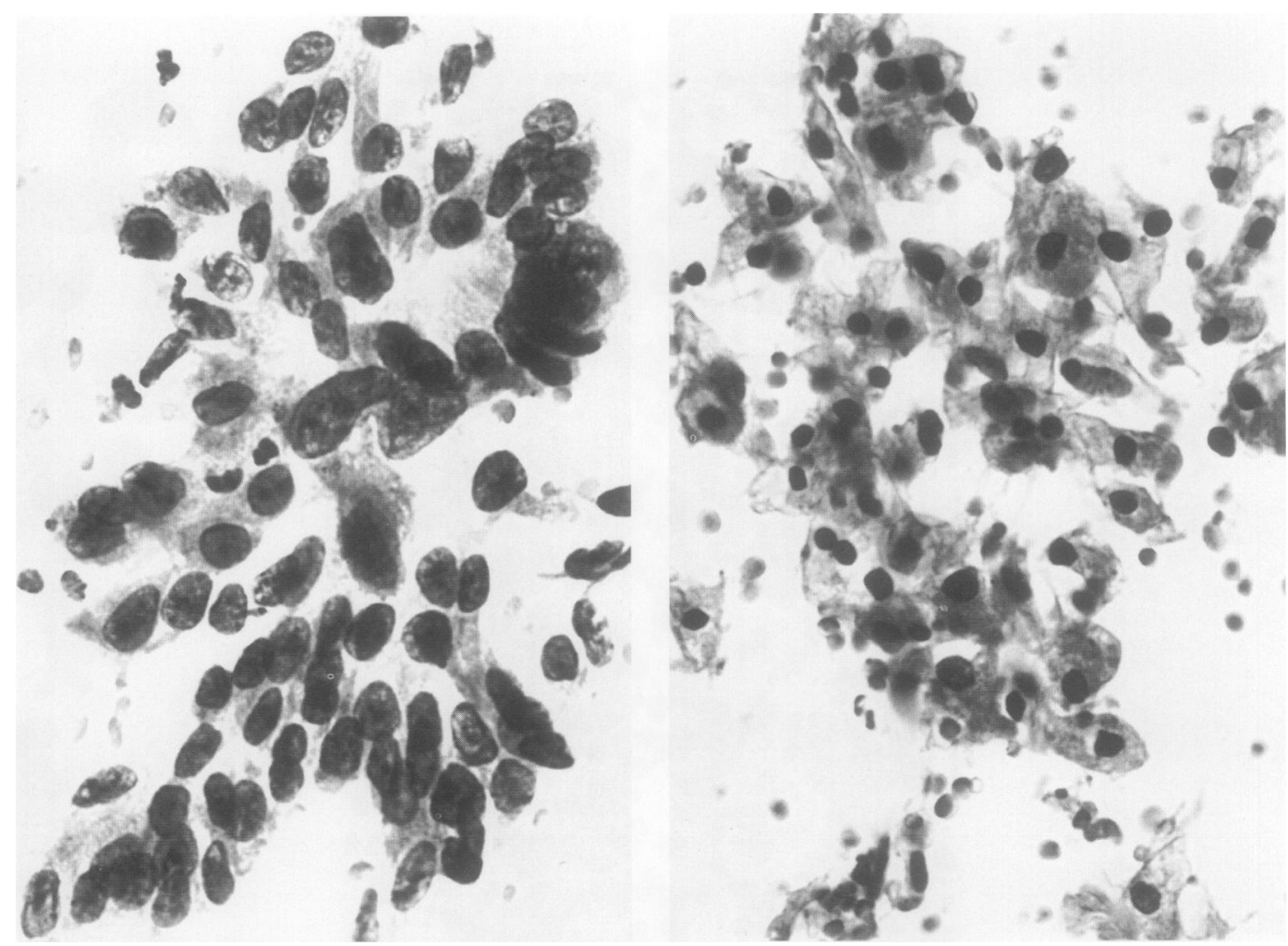

Figure 4 Case 16: (A) primary colonic adenocarcinoma; (B) primary clear cell renal carcinoma (haematoxylin and eosin). 
ïgure 5 Case 19: netastatic non-Hodgkin's umphoma in myocardium haematoxylin and eosin).

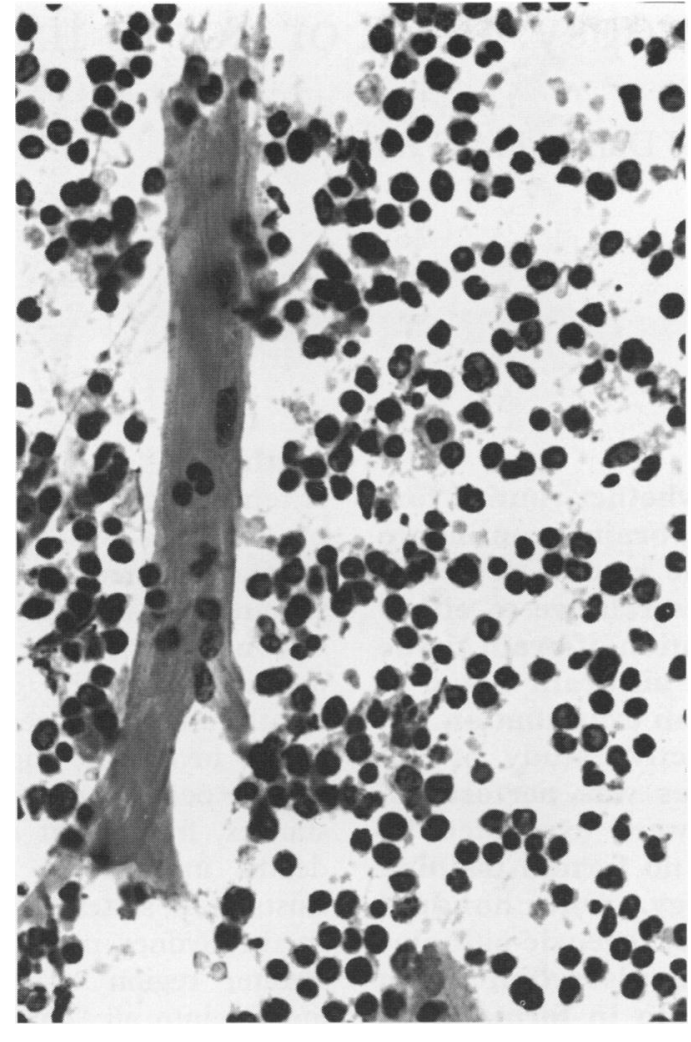

\section{Discussion}

Hospital necropsy rates have been in decline for years. ${ }^{2}$ The reasons for this are manyfold and include the attitudes of clinicians, pathologists, and relatives. ${ }^{34}$ Pathologists have to ensure that the necropsy is carried out rapidly and efficiently and that provisional and final reports are issued promptly. Issue of the final report, taking into account histological findings, is often delayed. ${ }^{5}$ There is a rapid decline in interest in the post mortem examination after gross findings have been discussed with clinicians. Consequently every effort should be made to provide as much relevant information as possible at the time of the necropsy. This is particularly true where unexpected pathology is uncovered such as previously undiagnosed tumours. Such cases accounted for up to $63 \%$ of post mortem examinations involving malignant tumours at Glasgow Royal Infirmary during 1992.
Investigation of undiagnosed or unsuspected tumours by frozen section has disadvantages. The technique is time consuming for MLSO staff who may have legitimate concerns about the infective potential of necropsy material. To sample more than one lesion demands further time. The quality of necropsy frozen sections is often poor and special stains - for example, for mucin-are usually inconvenient.

We have shown that cytological examination of tumours at the time of necropsy has advantages over frozen section. The technique is rapid and can be performed by the pathologist without MLSO support. Multiple sites of tumour, including bone marrow, can be sampled, stained, and assessed quickly and special stains for mucin performed in poorly differentiated lesions. The quality of cytological material is generally good, often better than frozen or even paraffin wax sections. Fixation and staining in the post mortem suite eliminates the risk of laboratory and cryostat contamination with infective organisms. Small lesions can be sampled without destroying them, thereby permitting demonstration of complete specimens and ultimately paraffin wax embedded histology. Finally, regular exposure to more and varied cytological material should be beneficial to all histopathology trainees.

Cytological examination of tumours is a rapid, accurate diagnostic technique for use with surgical specimens, ${ }^{6}$ but cytological techniques are appropriate to autopsy practice. Of several advantages, the ability to provide a rapid, accurate, and comprehensive provisional necropsy report is perhaps the greatest, and may help to stimulate an increase in requests for necropsies.

1 Howat AJ, Williams RA. Combined scrape cytology and frozen section histology for rapid diagnosis in breas pathology. Histopathology 1990;17:85-96.

2 Hill RB, Anderson RE. Pathologists and the autopsy. $A m$ Clin Pathol 1991;95(Suppl 1):S42-S9.

3 Stubbs F, Start RD, Hector-Taylor MJ, Cotton DWK The attitudes of junior pathologists towards the autopsy. 7 Pathol 1992;166:413-5.

4 Champ C, Tyler X, Andrews PS, Coghill SB. Improve your hospital autopsy rate to $40-50$ per cent, a tale of your hospital autopsy rate to $40-50$
two towns. $¥$ Pathol $1992 ; 166: 405-7$.

5 Whitty P, Parker C, Prieto-Ramos F, Al-Kharusi S Communication of results of necropsies in North Eas Thames region. BMF 1991;303:1244-6.

6 Sidawy MK, Silverberg SG. Intraoperative cytology. Back to the future? Am $\mathcal{F}$ Clin Pathol 1991;96:1-3. 